\title{
Investigating the Effect of Supply Chain Management on Sustainable Perfprmance Focusing on Environmental Collaboration
}

\author{
Bahareh Abbasi ${ }^{1}$, Hasan Farsijani ${ }^{2} \&$ Abbas Raad $^{3}$ \\ ${ }^{1}$ Graduate school of management, Shahid Beheshti University, Tehran, Iran \\ ${ }^{2}$ Department of industrial management, faculty of management and accounting, Shahid Beheshti University, \\ Tehran, Iran \\ ${ }^{3}$ Department of industrial management, faculty of management and accounting, Shahid Beheshti University, \\ Tehran, Iran
}

Corresponding author: Abbas Raad, Department of industrial management, faculty of management and accounting, Shahid Beheshti University, Tehran, Iran. Tel: 98-2990-5246. Email: a_raad@sbu.ac.ir

Received: July 2, 2016

Accepted: July 18, 2016

Online Published: August 6, 2016

doi:10.5539/mas.v10n12p115

URL: http://dx.doi.org/10.5539/mas.v10n12p115

\begin{abstract}
The purpose of this paper is proposing a comprehensive model that shows the effect of green supply chain management practices on sustainable performance focusing on environmental collaboration. 311 pieceworkers companies in the field of automotive, motorcycle and agricultural machinery were investigated. Questionnaire was used for collecting data. Structural equation model were used as a technique to analyzing the data. The results of analyzing data showed that green supply chain management practices have positive effect on sustainable performance and environmental collaboration. As mediating variable environmental collaboration has also positive effect on green supply chain management practices focusing on environmental collaboration on sustainable performance. Green supply chain can help increasing sustainable performance and environmental collaboration is also considered as an important capability for facilitating executing green supply chain management. Both positively impact society through improvements to the overall environment. This research is one of the few studies that explore the effect of green supply chain management practices on sustainable performance focusing on environmental collaboration. Green supply chain management practices plays an important role of each enterprise which is involved with supply chain activities and it will help increasing sustainable performance.
\end{abstract}

Keywords: green supply chain management practices, environmental collaboration, sustainable performance, structural equations

\section{Introduction}

These days, environment pollution is the main problem of earth that if it isn't investigated, can lead to the extinction of the human species potentially so doing appropriate actions in wide technologic scale and social, financial and political changes seem necessary. On of process that can be effective in each organization for considering this important problem and applying that in all work processes is managing supply chain. Supply chain management is management and coordination of a complex network of involved activities in delivering final product to the customer (Ninlawana, Seksan, Tossapol, \& Pilada, 2010). More beyond this definition, through adding green word, green supply chain management is introduced which refers to green procurement, green production, green distribution and reverse logistics, the idea behind green supply chain management is removing or minimizing wastes (energy, greenhouse, chemical and hazardous gas emissions, solid waste) along supply chain, environmental problems have been converted to the important concern for manufacturer under the law and the instructions of the customer, especially in the United States, Europe and Japan. Green supply chain management helps organization as an important innovation in developing strategies for achieving common goals of profit and market with reducing environmental dangers and increasing its environmental efficiency (Ninlawana, Seksan, Tossapol, \& Pilada, 2010; Hervani, Helms, \& Sarkis, 2005). In terms of product life circle, green supply chain management includes all steps of raw material, designing and making product, selling product and transportation, using product and recycling of products. If companies use green supply chain management, in addition to solving environmental problems can achieve to relative success in competitive 
advantage. In some of articles, six dimensions have been clarified for green supply chain management: green manufacturing and packaging, the environmental share, green marketing, green suppliers, green storage, designing a green economy. Green supply chain management actions include a set of optimal approaches and activities which are used by a company to integrate supply and demand and improve managing supply chain (Lee, 2008). Through adding (green) to the actions of supply chain management, green supply chain management include a set of green activities in providing and producing, distributing and reverse logistic (Ninlawana, Seksan, Tossapol, \& Pilada, 2010). Koh et al. (2007) showed that performing supply chain management can have some advantages such as reducing inventory levels, reducing the time in the production process, increasing flexibility, forecast accuracy, cost-saving and careful planning for sourcing. Companies which have implemented green supply chain management benefited cost-saving including material, energy and water saving and had better imagination of environmental responsibilities than other companies (Wisner, Tan, \& Leong, 2015). According to Pulraj (2011), environmental collaboration includes collaborating with suppliers for achieving environmental goals, improving the plans of reducing garbage, providing suppliers with specified designing that these designs include environmental requirements, encouraging suppliers for developing the strategy of reducing using new sources, working with suppliers for making production green and helping producers for providing material, requirements, pieces and services that support organizational goals. Moreover environmental collaboration is one of innovative answers to environmental problems, concentrating on protecting environment and promoting cultural development in terms of economic and environmental view.

\section{Literature Review}

\subsection{Green Supply Chain Management}

Green supply chain management is an environmental thinking that this definition includes production design, selection and sourcing of materials, production process, the final production delivered to the consumer and managing end of life production after using (Sirvastava, 2007). Hsu \& Hu (2010) evaluated the main approach to operating out green supply chain management. They have identified twenty approach and through AHP techniques. They prioritize approaches. The first three priorities obtained in this study contains: creating an environmental database for productions, senior management support and environmental assessment suppliers.

Wang et al. (2011) propose a multi-objective model that optimizes green supply chain. They considered variables such as transport cost, flow of production in supply chain and investment for environmental protection and then they have developed their own models. The results show that their model can be applied an effective tool in the strategic planning for green supply chain. Meanwhile, the sensitivity analysis provides some interesting managerial insights for firms.

Kotab et al. (2004) identified 34 indexes for green supply chain in the fild of retail and they classified these indexes in the eight categories contains: environmental management systems, use of energy, attention to inputs, productions, packing, transportations, consumption and waste products. Zhu et al. (2008) identified components for green supply chain management assessment in some industries in china such as electronic, petrochemical and automobile. With data collected from 341 chines manufactures, tow measurement models of GSCM practices implementation were tested and compared by confirmatory factor analysis. They classified these criteria in five categories, contains: internal management, green purches, collaboration with customers, recovery and design. This study contributes to the literature on empirical examination of the construct of GSCM practices implementation and to the practices of managers with a validated measurement scale to evaluate their strengths and weaknesses in different facets of implementing GSCM practices in their organizations.

Holt \& Ghobadian (2009) suggested internal environmental management practices, logistics, supplier assessment and evaluation, green procurement and logistics policy, supplier education and mentoring, and industrial networks as important green supply chain management. The purpose of this study is to examine the extent and nature of greening the supply chain in the UK manufacturing sector, and the factors that influence the breadth and depth of this activity.

Green et al. (2012) suggested that green supply chain management practices should include internal environmental management, green information systems, green purchasing, collaboration with customers, ecodesign and investment recovery. In this study data collected from 159 manufacturing managers were analyzed using a structural equation modeling methodology. Manufacturing managers provide data reflecting the degree to which their organizations work with suppliers and customers to improve environmental sustainability of the supply chain. Lee et al. (2012) noted that green supply chain management practices are composed of corporate and operational strategies to improve environmental sustainability such as internal environmental management, green purchasing, collaboration with customers and eco-design. This study developed a research model relating 
GSCM practice and business performance through three organizational variables (employee satisfaction, operational efficiency, and relational efficiency) as moderators. Starical analyses were based on the data collected, through survey questionnaires, from 223 SMes in the electronics industry in South Korea.

\subsection{Environmental Collaboration}

Sarkis (2003) provided further evidence that an increasing number of companies are adopting collaboration of environmental practices into their strategic plans and processes. The focus of this study will be on the components and elements of green supply chain management and how they serve as a foundation for the decision framework. Collaboration effort between focal company and supplier is the main ingredient of GSCM of facilitate supply- side environmentally and socially responsible activities. Collaboration in terms of environmental is an approach that helps firms to develop and support the environmental prowess of their supply partners (Klassen, \& Vachon, 2003). Environmental collaboration is one of the initiatives responses to environmental problems, focuses on environmental protection, and promotes coordinated development of economic and environment perspectives ( $\mathrm{Li}, 2011)$.

\subsection{Sustainable Performance}

Dimension of sustainability to achieve balance between economic, social and environmental have been provided and each of the elements in three dimensions are defined as follow:

Economic dimension: this dimension is considered as the most important dimension. In fact, it can be said without economic success, any supply chain will not survive for a long time.

Social dimension: this dimension attention to social needs of employees like fairness, health and employee benefits.

Environmental dimension: this dimension emphasis to environmental risks and deal with protection of the environment against industrial pollutions (Teut, Frank, Wittstruck \& David, 2010).

Researchers such as Pulraj (2011), Zhu \& Sarkis (2005), Holt \& Ghobadian (2009), Laosirhougthong \& Adebanj (2013), considered three important indicators to sustainable performance contains: economic performance, environmental performance, social performance.

\section{Conceptual Model and Research Hypotheses}

In 2005, Zhu et al. (2005) proposed 4 dimensions of green supply chain management that included environment interior management, exterior management, green supply chain management, environmental designing and recycling or capital recovery. Holet \& Ghobadian (2009) stated environment interior practices, preparations, evaluating sources, green purchase and green preparations policy, the knowledge of suppliers and consolers and industrial networks as the most important section of green supply chain management. According to Ninlawana et al. (2010), and Thoo et al. (2014), green supply, green distribution, green preparations are important dimensions of green supply chain practices that production section requires those for achieving sustainable performance. Pulraj (2011) looked for the relationship between sustainable management of supply and sustainable performance. In these studies, environmental collaboration was also proposed as a moderator of relationship between green supply chain management practices and sustainability that can facilitate green supply chain management practices. The companies that have relationships based on collaboration with suppliers can perform green supply chain management practices simply. According to Thoo Ay Chin (2015), the presence of environmental collaboration can facilitate green supply chain management practices to performing supply chain management be simplified. 


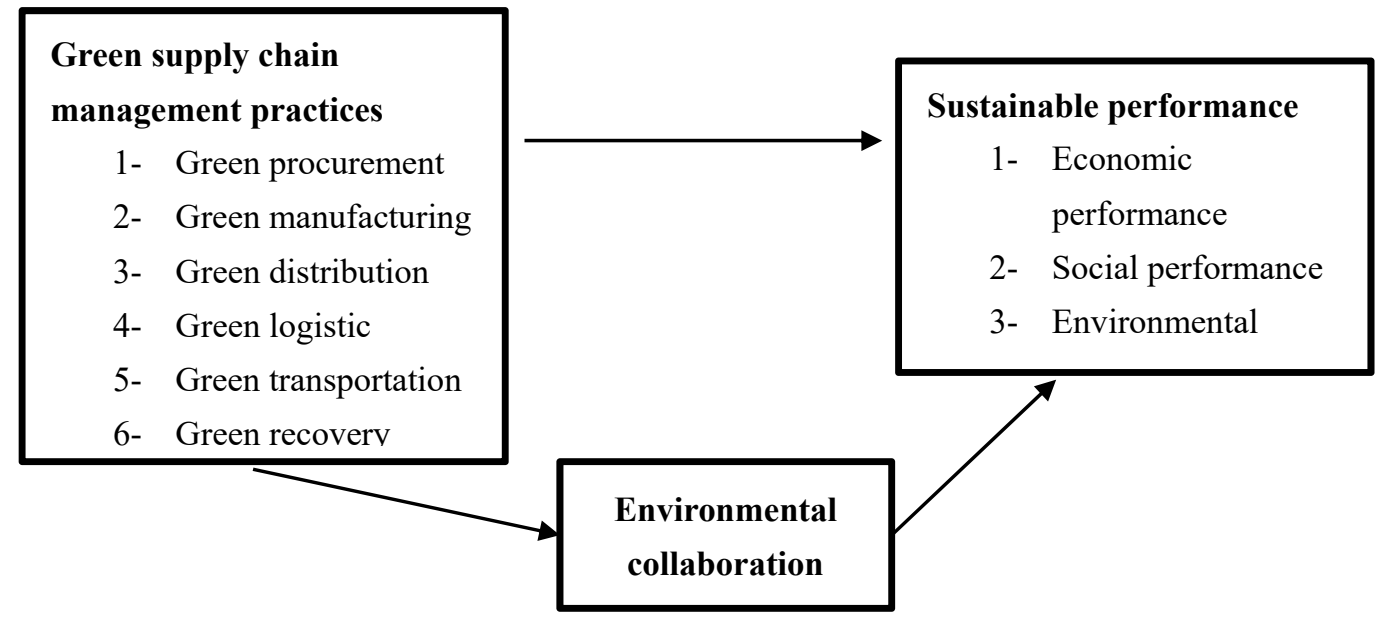

Figure 1. Research model

The goal of this article is proposing a comprehensive model which shows the effect of green supply chain management practices on sustainable performance focusing on environmental cooperation. For achieving that, below hypotheses are discussed:

First hypothesis: green supply chain management practices affect sustainable performance.

Second hypothesis: green supply chain management practices affect environmental collaboration.

Third hypothesis: environmental collaboration affects sustainable performance.

Fourth hypothesis: green supply chain management practices focusing environmental collaboration affect sustainable performance.

\section{Methodology}

In order to test above hypotheses, three industries are investigated that include pieceworkers of automotive, pieceworkers of motorcycle and pieceworkers of agricultural machinery. The numbers of each industry companies respectively are 1000, 200 and 200. Sampling method in this article is simple one and the number of sample is estimated using Cochran formula as 301 cases. The rate of distributing questionnaire in each industry is to the ratio of industry weight in whole statistical population. For assuring the validity of questionnaire content, content validity has been used. Content validity of this questionnaire is confirmed by professors and related books and articles to researching and providing required information and studying the questionnaires of articles and researchers and therefor has necessary validity.

In order to determine the reliability of questionnaire questions, Cronbach's alpha method has been used. The results are shown in table 2.

Table 1. Questionnaire Cronbach's alpha

\begin{tabular}{lll}
\hline & \multicolumn{2}{l}{ Cronbach's alpha } \\
Variable & Rate of alpha & Number of questions \\
\hline Green supply chain management actions & 0.829 & 14 \\
Environmental cooperation & 0.798 & 13 \\
Sustainable performance & 0.915 & 13 \\
Total & 0.852 & 40 \\
\hline
\end{tabular}

Considering obtained larger amount of alpha than 0.7 , it is identified that questionnaire has an ideal reliability. In this article, confirmatory factor analysis has been used for assuring data fitness obtained from researching and variables with related components to that. For testing hypotheses finally, structural equations have been used. For doing these analyses, PLS software is used. 


\section{Research Findings}

Through analyzing data of questionnaire, below findings will be obtained that will be explained as follows:

\subsection{Investigating the Normality of Research Variables}

Before entering the phase of testing hypotheses, it is necessary to be assuring about the normality of variables to use parametric or non-parametric test based on variables' normality or abnormality. For investigating the normality of pattern dimensions components, Kolmogorov and Smirnov test was used. The result of test is brought in table 3 .

Table 2. Kolmogorov and Smirnov test

\begin{tabular}{llll}
\hline Variable & Test statistic & Test significance level & Result \\
\hline Green supply chain management actions & .070 & .001 & Abnormal \\
Environmental cooperation & .054 & .029 & Abnormal \\
Sustainable performance & .057 & .016 & Abnormal \\
\hline
\end{tabular}

Considering the smaller amount of test significance level than 0.05 , it is clarified that data distribution is abnormal. Due to investigating research hypotheses and model fitness, PLs software has been used because of data abnormality. There are three hidden variables in this model. Hidden variable of green supply chain management by 14 observed variables, environmental collaboration variable by 13 observed variables and sustainable performance variable have been explained and measured by 13 observed variables. The model output is shown in Figures 2 and 3.

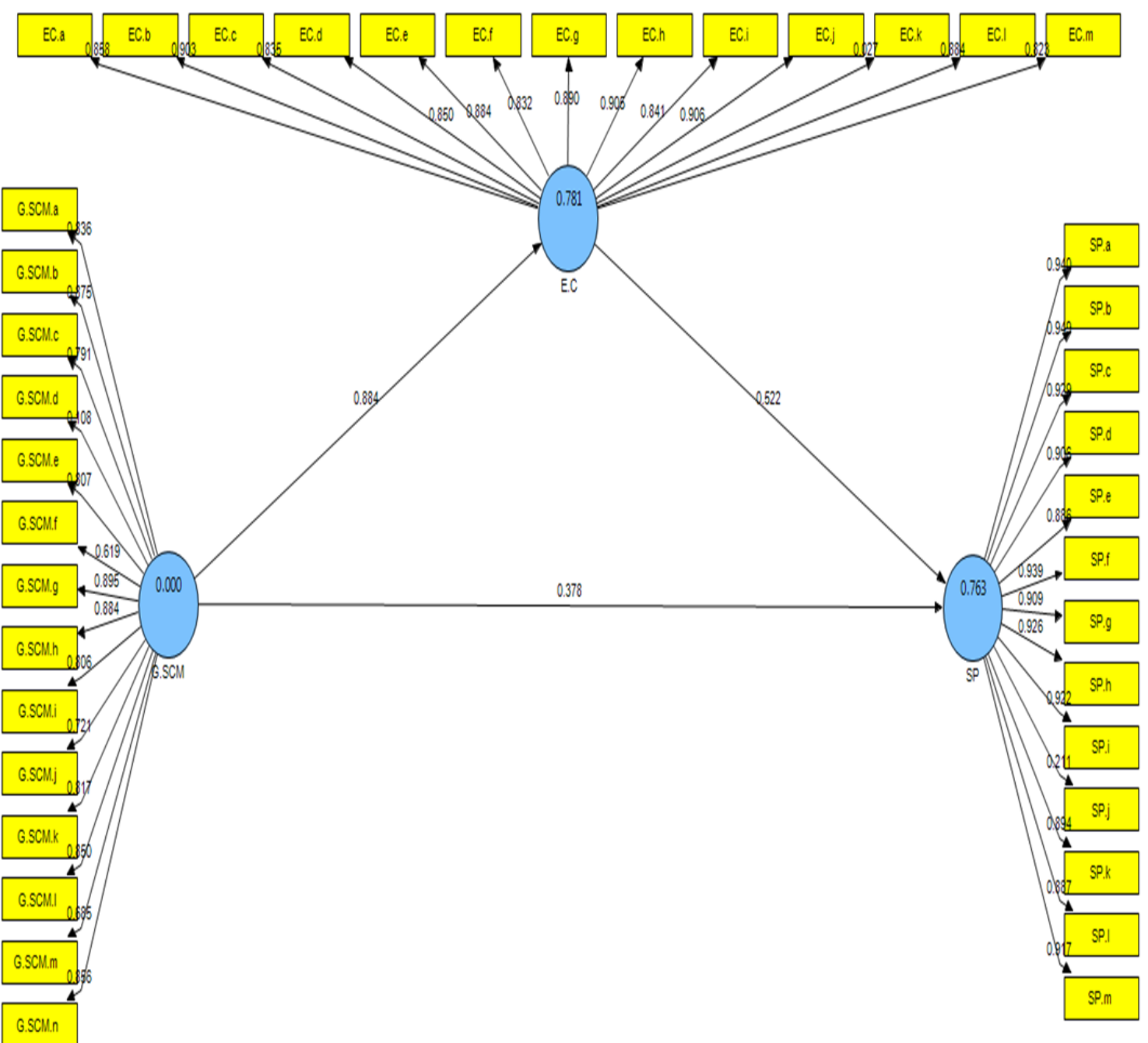

Figure 2. Coefficients diagram 


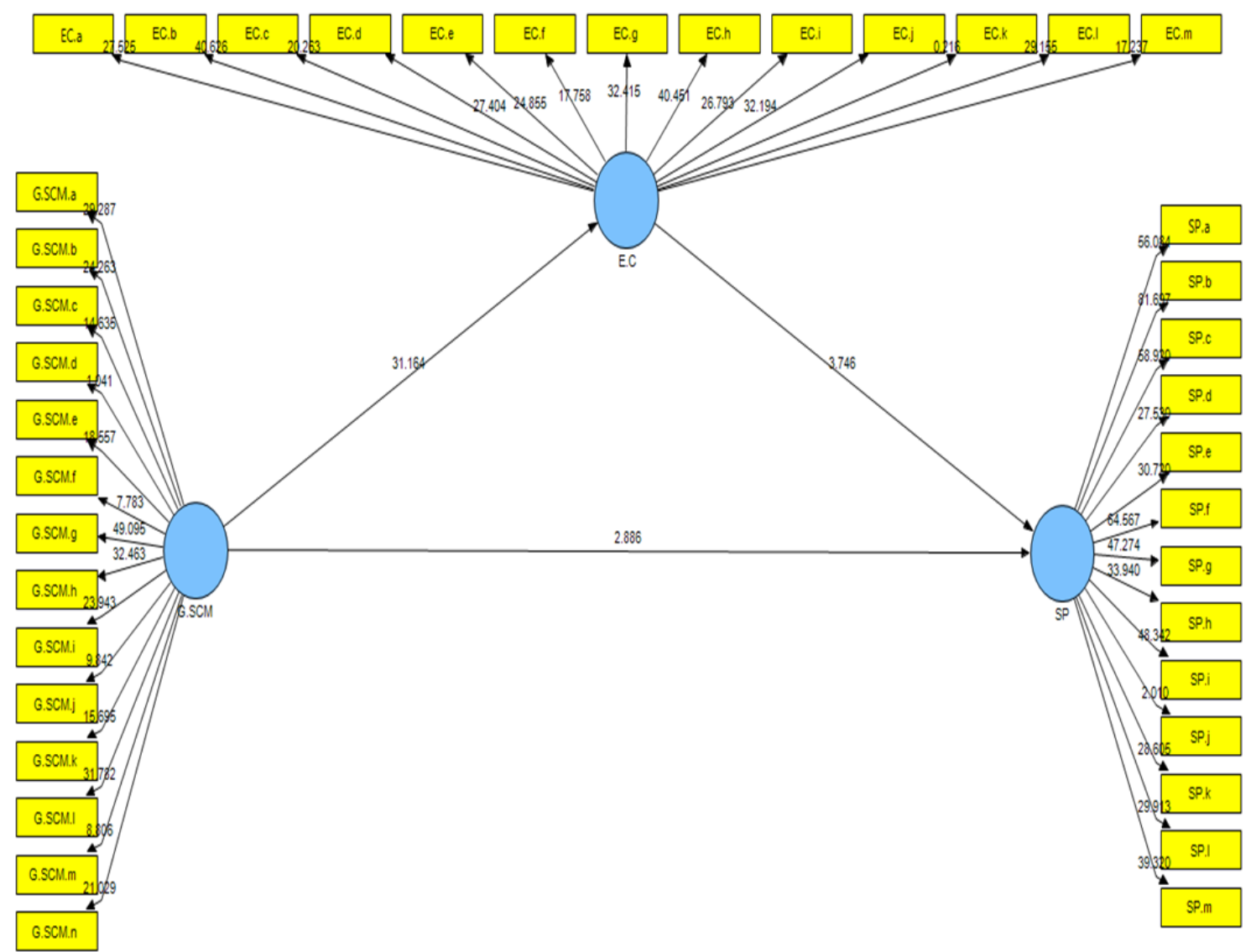

Figure 3. Significance level diagram

\subsection{Investigating the Coefficients of Load Factors and Significance (T Value) of Hidden Variables}

The coefficients of load factors show in what extant variables' changes are explained by observed variables. The coefficients of load factors of hidden variables are reported in table 4. Considering the table all load factors related to hidden variables are more than standard value of 0.4 which shows the appropriateness of this.

Table 3. The coefficients of load factors and significance

\begin{tabular}{|c|c|c|c|c|c|}
\hline Result & T significance level & Standard error & Load factor & Path & Variable \\
\hline Significant & 27.5254 & 0.0312 & 0.8575 & EC. $a<-$ E.C & \multirow{13}{*}{$\begin{array}{l}\text { Environmental } \\
\text { cooperation }\end{array}$} \\
\hline Significant & 40.6256 & 0.0222 & 0.9029 & EC.b $<-$ E.C & \\
\hline Significant & 20.2625 & 0.0412 & 0.8346 & EC.c $<-$ E.C & \\
\hline Significant & 27.4042 & 0.031 & 0.8504 & EC.d $<-$ E.C & \\
\hline Significant & 24.8555 & 0.0356 & 0.8839 & EC.e $<-$ E.C & \\
\hline Significant & 17.7577 & 0.0468 & 0.8317 & EC.f $<-$ E.C & \\
\hline Significant & 32.4155 & 0.0275 & 0.8902 & EC.g $<-$ E.C & \\
\hline Significant & 40.4513 & 0.0224 & 0.9047 & EC.h $<-$ E.C & \\
\hline Significant & 26.7928 & 0.0314 & 0.8409 & EC.i<- E.C & \\
\hline Significant & 32.1941 & 0.0282 & 0.9063 & EC.j<- E.C & \\
\hline Non-significant & 0.2156 & 0.124 & 0.0267 & EC.k $<-$ E.C & \\
\hline Significant & 29.1553 & 0.0303 & 0.8837 & EC.1<- E.C & \\
\hline Significant & 17.2372 & 0.0477 & 0.8227 & EC.m $<-$ E.C & \\
\hline Significant & 29.2868 & 0.0285 & 0.8356 & G.SCM.a <- G.SCM & \multirow{5}{*}{$\begin{array}{l}\text { Green supply } \\
\text { chain } \\
\text { management } \\
\text { actions }\end{array}$} \\
\hline Significant & 24.2632 & 0.0361 & 0.8747 & G.SCM.b <- G.SCM & \\
\hline Significant & 14.6353 & 0.0541 & 0.7912 & G.SCM.c <- G.SCM & \\
\hline Non-significant & 1.0407 & 0.1034 & 0.1076 & G.SCM.d <- G.SCM & \\
\hline Significant & 18.557 & 0.0435 & 0.8069 & G.SCM.e <- G.SCM & \\
\hline
\end{tabular}




\begin{tabular}{|c|c|c|c|c|c|}
\hline Significant & 7.7833 & 0.0795 & 0.6188 & G.SCM.f <- G.SCM & \multirow{22}{*}{$\begin{array}{l}\text { Sustainable } \\
\text { performance }\end{array}$} \\
\hline Significant & 49.095 & 0.0182 & 0.8953 & G.SCM.g <- G.SCM & \\
\hline Significant & 32.4632 & 0.0272 & 0.8842 & G.SCM.h <- G.SCM & \\
\hline Significant & 23.9429 & 0.0337 & 0.8058 & G.SCM.i <- G.SCM & \\
\hline Significant & 9.8423 & 0.0732 & 0.7208 & G.SCM.j <- G.SCM & \\
\hline Significant & 15.6954 & 0.052 & 0.8169 & G.SCM.k <- G.SCM & \\
\hline Significant & 31.7822 & 0.0268 & 0.8505 & G.SCM.1<- G.SCM & \\
\hline Significant & 8.8064 & 0.0777 & 0.6846 & G.SCM.m <- G.SCM & \\
\hline Significant & 21.0289 & 0.0407 & 0.8556 & G.SCM.n <- G.SCM & \\
\hline Significant & 56.0837 & 0.0168 & 0.9398 & SP.a $<-$ SP & \\
\hline Significant & 81.6969 & 0.0116 & 0.9491 & SP.b $<-$ SP & \\
\hline Significant & 58.9199 & 0.0158 & 0.9291 & SP.c $<-$ SP & \\
\hline Significant & 27.5304 & 0.0329 & 0.9059 & SP.d $<-$ SP & \\
\hline Significant & 30.72 & 0.0288 & 0.886 & SP.e $<-$ SP & \\
\hline Significant & 64.5668 & 0.0145 & 0.9391 & SP.f $<-$ SP & \\
\hline Significant & 47.2738 & 0.0192 & 0.9093 & SP.g $<-$ SP & \\
\hline Significant & 33.9401 & 0.0273 & 0.926 & SP.h $<-$ SP & \\
\hline Significant & 48.3419 & 0.0191 & 0.922 & SP.i $<-$ SP & \\
\hline Non-significant & 2.0103 & 0.105 & 0.211 & SP.j $<-$ SP & \\
\hline Significant & 28.6047 & 0.0313 & 0.8942 & SP.k $<-$ SP & \\
\hline Significant & 29.9133 & 0.0296 & 0.8869 & SP.1 <- SP & \\
\hline Significant & 39.3198 & 0.0233 & 0.9171 & SP.m $<-$ SP & \\
\hline
\end{tabular}

Considering the smaller amount of $\mathrm{t}$ significance level than 1.96 and smaller load factor than 0.4 for item "collaboration of supplier for reducing the use of electricity energy in stores" from environmental collaboration variable, the item "reducing fines because of damaging environment in production process" from sustainable performance variable and item "using raw material in packing with lower price and recyclable" from green supply chain management practices variable are removed from model. New model is developed as shape 4 (the coefficients of load factors) and Figure 5 (significance level).

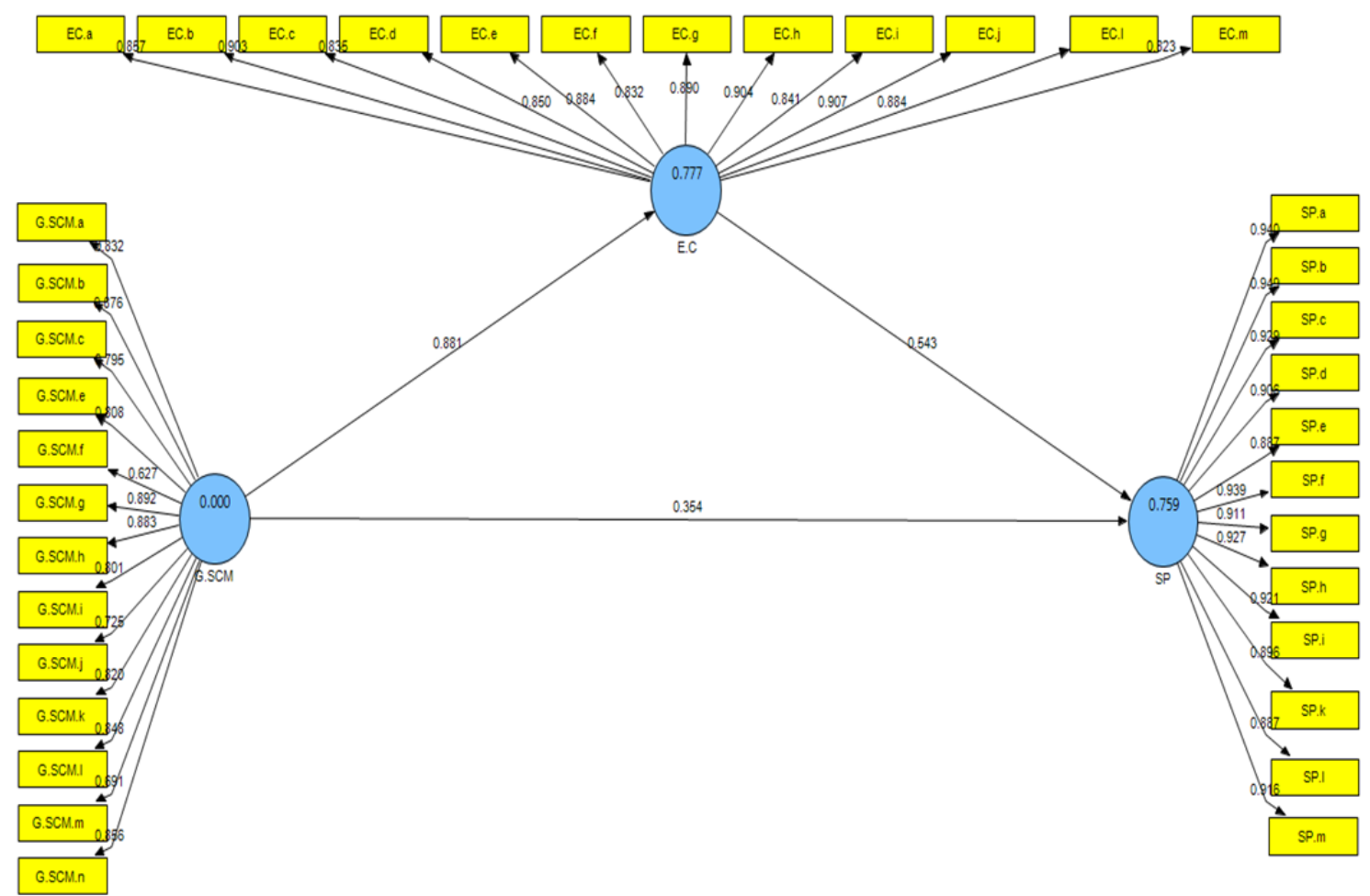

Figure 4. The diagram of investigating coefficients (modified model) 


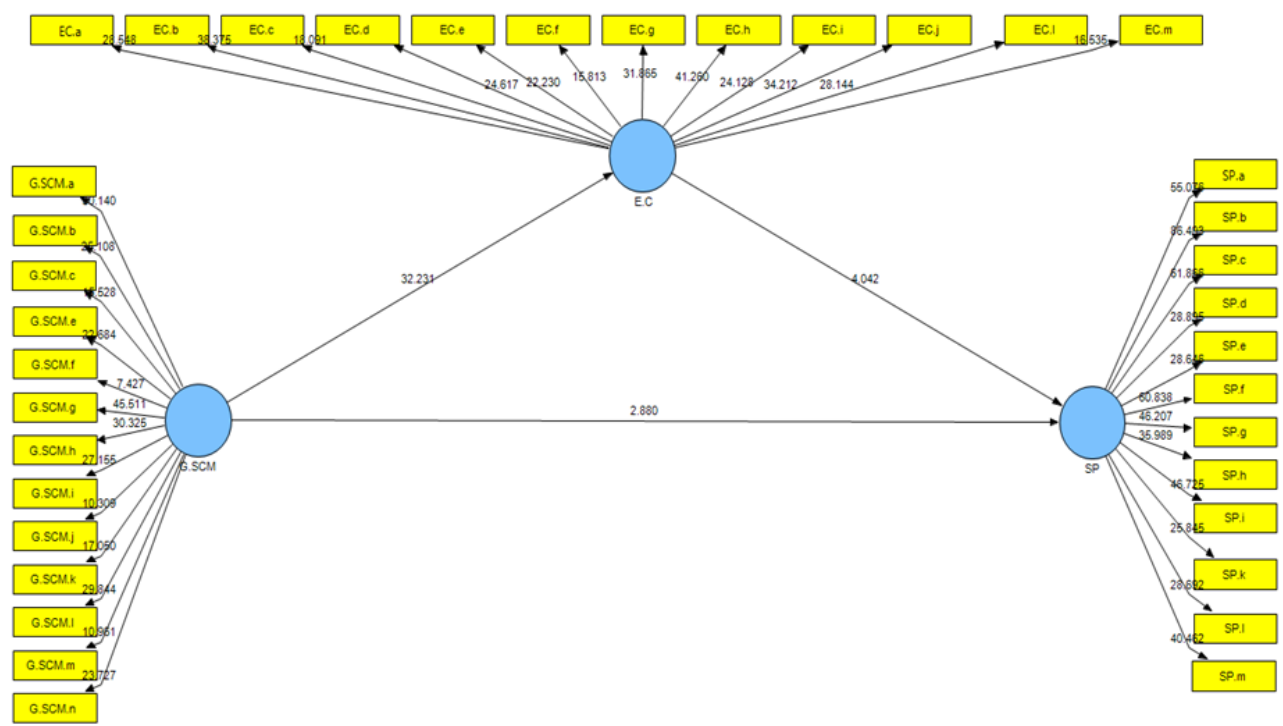

Figure 5. The diagram of significance level (modified model)

Reported load factors for hidden variable of environmental collaboration are respectively $0.8573,0.9028,0.8346$, $0.8501,0.8842,0.8319,0.8901,0.9045,0.8408,0.9065,0.8838$ and 0.823 that show all load factors are significant and related items explain hidden variable of environmental collaboration significantly. Load factors for hidden variable of green supply chain management practices are respectively 0.8765 ، 0.7946 ، 0.8079 ، 0.6268، 0.8923، 0.8835، 0.8011، 0.7251، 0.848 and 0.8561 that show all load factors are significant and related items explain hidden variable of green supply chain management practices significantly.

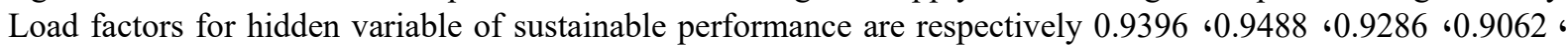
0.8868 0.9393 0.9105، 0.8871 and 0.9164 that all load factors are significant and 0.9269 0.921، related items explain hidden variable of sustainable performance significantly. Therefore out of assessing load factors, the coefficients of Cronbach's alpha and the reliability of hybrid structures will be investigated which is shown in table 5 .

Table 4. Cronbach's alpha and hybrid reliability

\begin{tabular}{lll}
\hline Variable & Hybrid reliability coefficient & Cronbach's alpha coefficient \\
& $>0.7$ & $>0.7$ \\
\hline Environmental collaboration & 0.9734 & 0.9701 \\
Green supply chain management practices & 0.9603 & 0.9552 \\
Sustainable performance & 0.9846 & 0.9829 \\
\hline
\end{tabular}

Considering the appropriate values for two mentioned indicators are bigger than 0.7 , it is clarified that all study hidden variables (structure) are in appropriate position. For investigating convergent validity, AVE index has been used which is shown in table 6 .

Table 5. Convergent validity

\begin{tabular}{ll}
\hline Variable & Extracted variance mean \\
\hline Environmental collaboration & 0.753 \\
Green supply chain management practices & 0.652 \\
Sustainable performance & 0.841 \\
\hline
\end{tabular}

Considering the appropriate value for mentioned indicator is bigger than 0.5 , it is clarified that all study hidden variables (structure) are in appropriate position. $\mathrm{R}$ square criterion represents an external variable (independent variable) on an internal variable (dependent variable). This criterion is shown in Table 7 for the model. 
Table 6. Investigating the criterion R square

\begin{tabular}{ll}
\hline Variable & R Square \\
\hline Environmental collaboration & 0.7768 \\
Green supply chain management practices & - \\
Sustainable performance & 0.7592 \\
\hline
\end{tabular}

Considering the standard value of this index which is higher than 0.33 , it is as average criterion and 0.67 as strong one. Reported numbers in table 7 show that $\mathrm{R}$ square criterion for all variables is in strong position. Redundancy criterion represents the changeability of an internal structure indexes that are affected by one or several external structures. Whatever this value is more; it will show more appropriate fitness of structural section of model. This index is 0.558 in this article model which shows ideal fitness of model. For investigating quality or validity of model, credit investigation which includes common credit check index (CV COM) and check the validity of redundancy or redundancy index (CV RED) has been used. Common index evaluates the quality of measuring each block. Redundancy index considering measuring model evaluates the quality of structural model for each internal block. Positive values of these indexes represent appropriate and acceptable quality of measuring and structural model. In table 8 , the values of each one of related indexes to independent and dependent variables have been shown. As it can be observed indexes are positive and more than zero so relying on these indexes, model is confirmed.

Table 7. CV RED and CV COM criteria

\begin{tabular}{lrl}
\hline Variable & CV red & CV com \\
\hline Environmental collaboration & 0,584 & 0.753 \\
Green supply chain management practices & 0.653 & 0.653 \\
Sustainable performance & 0.634 & 0.838 \\
\hline
\end{tabular}

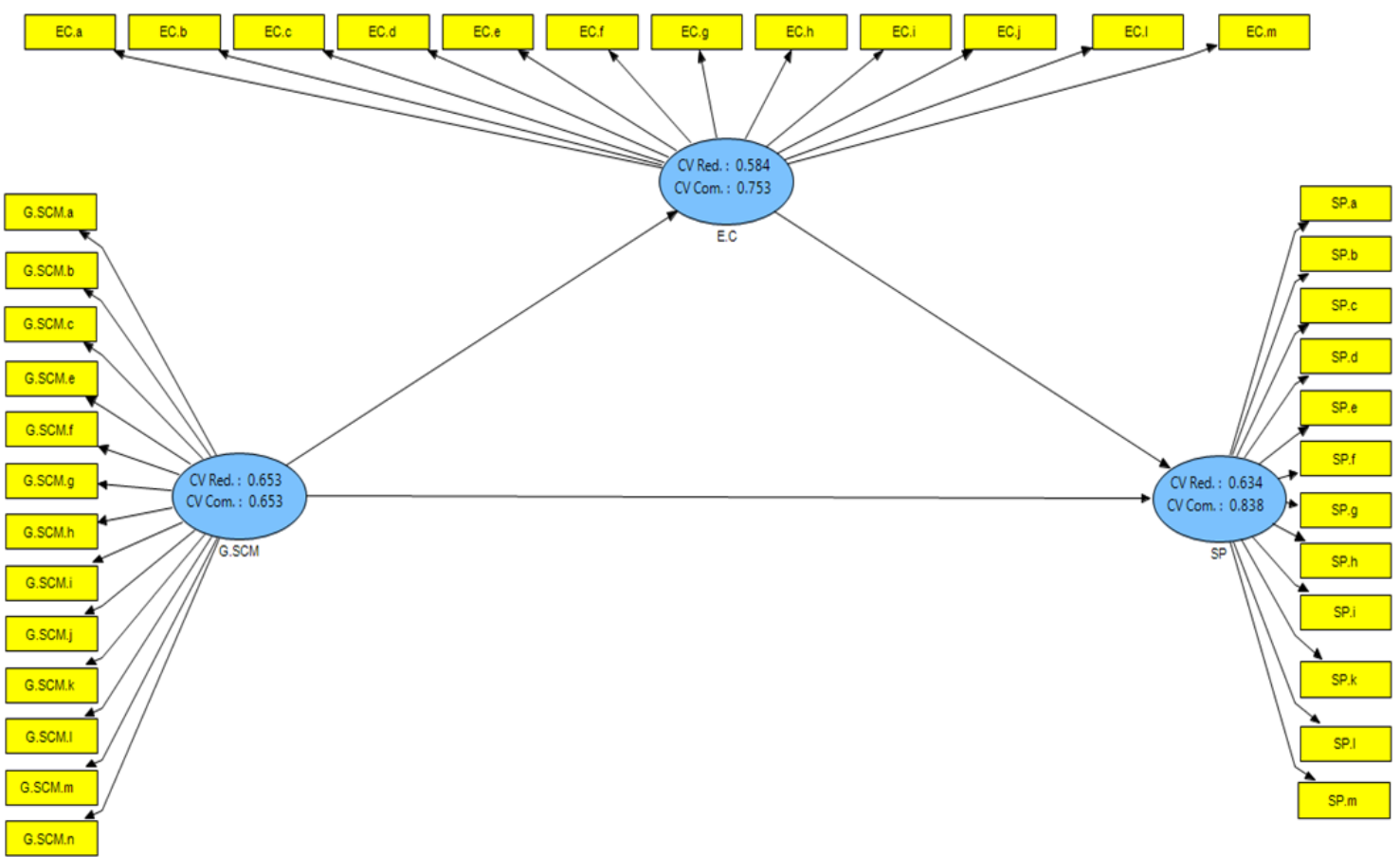

Figure 6. The diagram of investigating CV RED and CV COM criteria

For investigating total fitness of mode, GOF index has been used. This criterion is calculated through multiplied of the square root of the mean values of common and the average R Square. 
Table 8 . Communality values

\begin{tabular}{ll}
\hline Variable & Communality \\
\hline Environmental collaboration & 0.7534 \\
Green supply chain management practices & 0.6526 \\
Sustainable performance & 0.8417 \\
\hline
\end{tabular}

Considering Table 9, it is clarified that the mean of common values is 0.749 . The reported R Square mean also in Table 7 is 0.768 . Considering mentioned values the rate of GOF index is 0.758 that standard limit of this index (0.36) shows appropriate situation.

\subsection{Checking Hypotheses}

First hypothesis: green supply chain management actions affect sustainable performance.

Table 9. Checking first hypothesis

\begin{tabular}{lllll}
\hline Hypothesis & $\begin{array}{l}\text { Path } \\
\text { coefficient }\end{array}$ & $\begin{array}{l}\text { Standard } \\
\text { error }\end{array}$ & $\begin{array}{l}\text { T } \\
\text { Significance } \\
\text { level }\end{array}$ & Test result \\
\hline $\begin{array}{l}\text { First hypothesis: Green supply chain management } \\
\text { practices affect sustainable performance. }\end{array}$ & 0.354 & 0.122 & 2.880 & $\begin{array}{l}\text { Hypothesis } \\
\text { confirmation }\end{array}$ \\
\hline
\end{tabular}

In confidence level of 0.95 based on the results of table 10, correlation coefficient (load factor) is 0.354 . Considering the larger amount of $\mathrm{T}$ significance level than 1.96, it is clarified that green supply chain management practices affect sustainable performance therefor zero hypothesis is rejected and study hypothesis is confirmed.

Second hypothesis: green supply chain management actions affect environmental collaboration.

Table 10. Checking second hypothesis

\begin{tabular}{lllllll}
\hline Hypothesis & & $\begin{array}{l}\text { Path } \\
\text { coefficient }\end{array}$ & $\begin{array}{l}\text { Standard } \\
\text { error }\end{array}$ & $\begin{array}{l}\text { T } \\
\text { Significance } \\
\text { level }\end{array}$ & Test result \\
\hline $\begin{array}{l}\text { Green supply chain management } \\
\text { environmental collaboration. }\end{array}$ & practices & affect & & & & \\
\hline
\end{tabular}

In confidence level of 0.95 based on the results of Table 11, correlation coefficient (load factor) is 0.881 . Considering the larger amount of $\mathrm{T}$ significance level than 1.96, it is clarified that green supply chain management practices affect environmental collaboration therefor zero hypothesis is rejected and study hypothesis is confirmed.

Third hypothesis: environmental collaboration affects sustainable performance.

Table 11. Checking third hypothesis

\begin{tabular}{lllllll}
\hline Hypothesis & & & $\begin{array}{l}\text { Path } \\
\text { coefficient }\end{array}$ & $\begin{array}{l}\text { Standard } \\
\text { error }\end{array}$ & $\begin{array}{l}\text { T } \\
\text { Significance } \\
\text { level }\end{array}$ & Test result \\
\hline $\begin{array}{l}\text { Environmental } \\
\text { performance. }\end{array}$ & cooperation & affects & sustainable & & & \\
\hline
\end{tabular}

In confidence level of 0.95 based on the results of Table 12, correlation coefficient (load factor) is 0.543 . Considering the larger amount of $\mathrm{T}$ significance level than 1.96, it is clarified that environmental collaboration affect sustainable performance therefor zero hypothesis is rejected and study hypothesis is confirmed.

Fourth hypothesis: green supply chain management practices focusing environmental collaboration affect 
sustainable performance.

Table 12. Checking fourth hypothesis

\begin{tabular}{llllll}
\hline Hypothesis & & $\begin{array}{l}\text { Path } \\
\text { coefficient }\end{array}$ & $\begin{array}{l}\text { Standard } \\
\text { error }\end{array}$ & $\begin{array}{l}\text { T significance } \\
\text { level }\end{array}$ & Test result \\
\hline $\begin{array}{l}\text { Green supply chain management practices } \\
\text { focusing environmental } \\
\text { sustainable performance. }\end{array}$ & collaboration affect & 0.751 & 0.0427 & 17.5898 & $\begin{array}{l}\text { Hypothesis } \\
\text { confirmation }\end{array}$ \\
\hline
\end{tabular}

In confidence level of 0.95 based on the results of Table 13, correlation coefficient (load factor) is 0.751 . Considering the larger amount of $\mathrm{T}$ significance level than 1.96, it is clarified that green supply chain management focusing environmental collaboration affect sustainable performance therefor zero hypothesis is rejected and study hypothesis is confirmed.

\section{Conclusion}

For analyzing collected data in this article from 311 companies through inferential statistic, the situation of research variables was investigated by central tendency and dispersion. In final step, hypotheses were checked through structural equations approach by PLS software. The results of initial factor analysis showed that three items didn't have significant load factor and as result were removed from model. In next level after removing mentioned items, model was confirmed and fitness indexes were ideal. Eventually the results of research showed that all four hypotheses of this research are confirmed.

The results of first, second and fourth hypotheses are aligned with the results of many previous researches. For example, zhu et al. (2005), proposed 4 dimensions of green supply chain management practices that included environment interior management, exterior management, green supply chain management, environmental designing and recycling or capital recovery. Holet \& Ghobadian (2009) stated environment interior practices, preparations, evaluating sources, green purchase and green preparations policy, the knowledge of suppliers and consolers and industrial networks as the most important section of green supply chain management. According to Ninlawana et al. (2010), and Thoo et al. (2014), green supply, green distribution, green preparations are important dimensions of green supply chain practices that production section requires those for achieving sustainable performance. Green et al. (2012), recommended that green supply chain management practices should include interior management, green information service, and green purchase, collaboration with customers, compatible designing with environment and improving investment. Lee et al. (2012) mentioned that green supply chain management practices consist of operational strategies and collaboration for improving environmental sustainability such as environment interior management, green purchase, and collaboration with customers and compatible designing with environment. The results of third hypothesis are aligned with the results of Holet \& Ghobadian (2009), Pulraj (2011), and Thoo Ai Chin et al. (2015). Holet \& Ghobadian (2009) used foreign supply chain management for observing the effect of environmental collaboration on organization's sustainable performance. Pulraj (2011) looked for relationship between managing sustainable supply and sustainable performance. In these studies also environmental collaboration was proposed as a moderating case for relationship among green supply chain management practices and sustainability that can facilitate green supply chain management practices. The companies which have relationships based on collaboration with providers can perform green supply chain management practices simply. In order to perform future researches, a mathematical model is recommended to be proposed for green supply chain management practices targeting reducing cost, reducing carbon dioxide emissions and increase customer and suppliers satisfaction. Using multi-criteria decision making methods are also recommended in order to ranking the rate of green supply chain management practices effectiveness on sustainable performance. Proposing evaluation model of study companies' performance considering the criteria of sustainable performance, environmental collaboration and green supply chain management practices can also be investigated as the other research subject.

\section{References}

Green, Jr. K. W., Zelbst, P. J., Meacham, J., \& Bhadauria, V. S. (2012). Green supply chain management practices: impact on performance supply chain management. An International Journal, 17(3), 290-305.

Hervani, A. A., Helms, M. M., \& Sarkis, S. (2005). Performance measurement for green supply chain management. Benchmarking: An International Journal, 12(4), 303-353. 
Holt, D., \& Ghobadian, A. (2009). An empirical study of green supply chain management practices amongst UK manufactures . Journal of Manufacturing, Technology Management, 20(7), 933-956.

Hsu, C. W., \& Hu, A. H. (2010). Green supply chain management in the electronic industry, international gournal of environ. Sci. Tech., 5(2), 205-2016.

Klassen, R. D., \& Vachon, S. (2003). Collaboration and evaluation in the supply chain: the impact of plant-level environmental investment (Vol. 12, No. 3, pp. 336-352).

Koh, S. C. L., Demirbag, M., Bayraktar, E., Tatoglu, E., \& Zaim, S. (2007). The impact of supply chain management practices on performance of SMEs. Industrial Management \& Data Systems, 107(1), 103-124.

Kotab Massaki, \& Kristain Helsen (2004). Global marketing management. John Wily \& Soun Inc. Business \& Economics, 144, 157.

Laosirhougthong, T., Adebanj, D., \& Tan, K. C. (2013). Green supply chain management practices and performance. Industrial Management \& Data Systems, 113(8), 1088-1109.

Lee, S. M., Kim, St., \& Choi, D. (2012). Green supply chain management and organization performance. Industry Management \& Data System, 112(8), 1088-1109.

Lee, S. Y. (2008). Drivers for the participation of small and medium size suppliers in green supply chain initatives. Supply Chain Management International Journal, 13(3), 185-198.

Li, Y. (2011). Research on the performance measurement of green supply chain management in china. Journal of Sustainable Development, 4(3), 101-107.

Ninlawana, C., Seksan, P., Tossapol, K., \& Pilada, W. (2010, March). The Implementation of green supply chain management practices in electronics Industry. Proceeding of the International Milticonference of Engineers and Computer Scientist, 3(1), 17-19, Hong Kong.

Pulraj, A. (2011). Understanding the relationship between internal resources and capabilities, sustainable supply management and organizational sustainability. Journal of Supply Chain Management, 47(1), 19-37.

Sarkis, J. (2003). A strategic decision making framework for green supply chain management. Journal of Cleaner Production, 11(4), 397-409.

Sirvastava, S. K. (2007). Green supply chain management: A state-of-the-art literature review. International Journal of Management Review, 9(1), 53-80.

Teut, B., Frank, Wittstruck, \& David (2010). A systematic review of sustainable supply chain management research. What is there and what is missing? MKW 2010-Betriebliches. Unwell and Nachhaltigkeits Management, 1001-1015.

Thoo, A., Abdul Hamid, Ab., Rasli, A., \& Zhung, D. (2014). The moderating effect of enviropreneurship on green supply chain management practices and development of Industry and Economy. Advance Material Research, 869-870, 773-776.

Thoo, A., Chin, H. H., \& Tat, Z. S. (2015). Green supply chain management, environmental collaboration and sustainability performance. Procedia CIRP Journal, 26(1), 695-699.

Wang Fan, Xiaofan Lai, \& Ning Shi (2011). A multi-objective optimization for green supply chain network design. Decision Support Systems Journal, 51(2), 262-269.

Wisner, J. D., Tan, K. C., \& Leong, G. K. (2015). Principles of supply chain management: A balanced approach (4th Eds.). Cengage Learning, Mason, South-Western.

Zhu, Q. H., Sarkis, J., \& Yong, G. (2005). Green supply chain management in china: pressures practices and performance, in china: pressures, practices and performance. International Journal of Operations \& Production Management, 25(5), 449-468.

Zhu, Q., Sarkis, J., \& Kee Hung, L. (2008). Confirmation of a measurement model for green management practices implementation. International Journal of Production Economics, 111(2), 261-73.

\section{Copyrights}

Copyright for this article is retained by the author(s), with first publication rights granted to the journal.

This is an open-access article distributed under the terms and conditions of the Creative Commons Attribution license (http://creativecommons.org/licenses/by/4.0/). 